\title{
sciendo
}

\section{Prevalence of Urinary Incontinence in High-Impact Sport Athletes: A Systematic Review and Meta-Analysis}

\author{
by \\ Telma Pires ${ }^{1}$, Patrícia Pires ${ }^{1}$, Helena Moreira ${ }^{2}$, Rui Viana ${ }^{3}$
}

\begin{abstract}
The aim of this study was to systematize the scientific evidence that assessed the prevalence of urinary incontinence in female athletes and determine which modality is most predisposed to stress urinary incontinence. From September to December 2018, a systematic literature search of current interventional studies of stress urinary incontinence of the last ten years was performed using PubMed, EMBASE, Scopus and Web of Science databases. The methodological quality was assessed by the Downs and Black scale, while the data collected from the studies were analyzed through meta-analysis. Nine studies met the eligibility criteria, meaning they included reports of urinary incontinence in different sports. The meta-analysis showed $25.9 \%$ prevalence of urinary incontinence in female athletes in different sports, as well as $20.7 \%$ prevalence of stress urinary incontinence. The most prevalent high impact sport was volleyball, with the value of $75.6 \%$. The prevalence of urinary incontinence can be high in female athletes, with high-impact sports potentially increasing the risk for stress urinary incontinence. Further research is needed regarding the potential risk factors related to the onset of urinary incontinence.
\end{abstract}

Key words: exercise, female athletes, pelvic floor muscle, stress urinary incontinence.

\section{Introduction}

The International Continence Society (ICS) and the International Urogynecological Association (IUGA) define urinary incontinence (UI) as a symptom, namely the complaint of any involuntary leakage of urine (Haylen et al., 2010). The most frequent form of UI in women is stress urinary incontinence (SUI) which appears to be a common problem in the last decade among nulliparous young women (Da Roza et al., 2012, $2015 b)$. The mean prevalence in various studies is $30 \%$ among middle-aged women, reaching $47 \%$ in women who exercise regularly (Thomaz et al., 2017), having a significant impact on their quality of life (Abrams et al., 2010; Maia et al., 2015; Viana et al., 2015). SUI may be a barrier to women's participation in sport and fitness activities. Therefore, it may be a threat to women's health, self-esteem and well-being (Bø, 2004; Viana et al., 2015).

Several studies have documented that young women, especially those practicing high impact sports, are considered to be at greater risk for developing SUI (Hagovska et al., 2017; Leitner et al., 2016). SUI in athletes is related to how frequently athletes are subjected to increased intra-abdominal pressure, which is caused by a contraction of the abdominal muscles in highimpact activities without proper awareness and strengthening of the perineal muscles (Bø, 2004; Borin et al., 2013; Teixeira et al., 2018). Strenuous physical activity that involves intra-abdominal pressure can overload and chronically damage the perineum (including the periurethral striated muscle), thus decreasing the contraction strength of the pelvic floor muscle (PFM) and increasing the risk for SUI (Borin et al., 2013; Da Roza et al.,

\footnotetext{
1 - University of Trás-os-Montes and Alto Douro, Vila Real, Portugal.

2 - Department of Sports, Exercise and Health Sciences, CIDESD, CITAB, University of Trás-os-Montes and Alto Douro, Vila Real, Portugal.

3 - Hospital de S. João - Porto/ University of Fernando Pessoa, Porto, Portugal.
} 
2015b; Reis et al., 2011). Another factor is muscle fatigue, which occurs during physical activity when type II fibers are recruited. These fibers have a low capacity for maintaining the muscle tone of the PFM, one of the factors that can compromise the UI mechanism (Reis et al., 2011; Teixeira et al., 2018; Thomaz et al., 2017). This can adversely affect the quality of life causing embarrassment, anxiety and reduced participation in social activities (Da Roza et al., 2012; Viana et al., 2015). Therefore, it is important to establish a complete diagnosis, through questionnaires on the quality of life and urine quantification tests (Jeyaseelan et al., 2000). Numerous studies have concluded that pelvic floor muscle training (PFMT) is an effective therapy for SUI (Ferreira et al., 2014; Leitner et al., 2019; Oliveira et al., 2017; Sousa et al., 2015).

The aim of this study was to systematize the scientific evidence that assessed the prevalence of UI in female athletes and determine which modality is most predisposed to SUI.

\section{Methods}

This systematic review was registered in the PROSPERO database (CRD42019116085) (www.crd.york.ac.uk/prospero), and followed the recommendations of the PRISMA guidelines (Moher et al., 2015).

\section{Search strategy and eligibility criteria}

To identify relevant articles, a bibliographic search was carried out in four electronic databases, i.e., PubMed, EMBASE, Scopus and Web of Science, between September and December of 2018. The search used the following filters: "humans", "English and Portuguese language" and "10 years" and the following keywords: "High-impact" OR "Sport" (MeSH) OR "Exercises" (MeSH) AND "Female athletes" (MeSH) AND "Pelvic Floor Muscle" AND "Stress urinary incontinence" (MeSH). This specific research period was selected due to a notable increase in the scientific literature investigating the prevalence of SUI in high-impact sports in the last decade. Nine hundred thirty potentially relevant articles were found. The study selection flow chart is shown in Figure 1. These studies are quasi-experimental and observational. They involved athletes with UI symptoms, with the mean age between 18 and 45 years. The exclusion criteria were studies including participants who had had previous pelvic surgery, the elderly, women in their menopause, pregnant and parous women who were at least 12 months postpartum, other reviews or meta-analysis, and case studies.

\section{Quality assessment}

The methodological quality assessment was performed independently by two reviewers (TP and RV), using the Downs and Black scale (Downs and Black, 1998) for randomized and non-randomized studies. There were 27 items that assessed domains reporting, the external validity, study bias, confounding/selection bias and power of the study. For the assessment of the observational studies, an adaptation was performed, as suggested by the Cochrane Collaboration (Collaboration), excluding items related to experimental studies and Cohort and case-control studies $[4,7,8,13,14,15,17,19$, 21$24,27]$ because they did not fit the methodological design of the analyzed studies (Table 1). In this systematic review, studies were classified as having high methodological quality when they presented scores $\geq 70 \%$ on the scale (19 points for a randomized controlled trial, 10 points for case control and cohort studies, 9 points for observational studies and 8 points for crosssectional studies). Any disagreement between the reviewers was resolved by consensus.

\section{Statistical Analysis}

Despite the heterogeneity in the design and sample size of the nine studies analyzed, it was possible to carry out a meta-analysis. A descriptive analysis of the studies included in the systematic review was also performed. A generalised linear mixed model (GLMM) - more specifically, a random intercept logistic regression model - was used for the meta-analysis of the proportions of UI and SUI. The meta-analysis was performed using the Package meta (Schwarzer, 2007), available for program $R$ (Team, 2016). The heterogeneity was evaluated with the Cochran's $Q$ Test and the $I^{2}$ statistic of Higgins and Thompson. The Cochran's $Q$ test evaluates the null hypothesis of the existence of homogeneity between the samples, with the studies being considered homogeneous if this hypothesis is not rejected, that is, if $p>0.05$, with a level of significance of $5 \%$. The $\mathrm{I}^{2}$ statistic of Higgins and Thompson ranges from $0 \%$ (negative values are adjusted to $0 \%$ ) to $100 \%$, being $0 \%$ indicative of absence of heterogeneity. Higgins et al., (2003) proposed to 
classify the heterogeneity as low for values close to $25 \%$, moderate for values close to $50 \%$ and high for values near or greater than $75 \%$.

\section{Results}

\section{Study Selection}

The search strategy yielded 930 potentially relevant studies of which 454 duplicate records were removed. A selection process based on titles and abstracts led to the exclusion of 303 studies. After applying the inclusion and exclusion criteria, 174 studies were excluded, and 71 studies entered the full-text review. From those, 38 were excluded, with the reasons for exclusion being presented in the PRISMA flowchart. In total, 9 studies were included (Figure 1).

\section{Study Characteristics}

Study characteristics are presented in Table 1. Most studies were cross-sectional $(n=6)$, with a prospective/observational design $(\mathrm{n}=1)$, an experimental study $(\mathrm{n}=1)$ and a non-randomized controlled trial $(n=1)$. The systematic review identified nine studies conducted between 2010 and 2018. They included a total sample of 1254 participants, with an average age of $22.8( \pm 6.1)$ years. Nine studies included the prevalence of UI, with 8 including the prevalence of SUI.

\section{Quality Assessment}

The methodological quality of the studies was assessed using the Downs and Black scale. Six studies (Da Roza et al., 2015a, 2015b; Hagovska et al., 2017; Jácome et al., 2011; Leitner et al., 2016; Poświata et al., 2014) were considered of high quality, reaching a score $\geq 70 \%$, while the others presented low methodological quality (Borin et al., 2013; Ferreira et al., 2014; Rivalta et al., 2010) (Table 2).

\section{Prevalence of Urinary Incontinence}

The prevalence of the studies included in the meta-analysis was $25.9 \%$ (95\% confidence interval (CI): $23.5-28.3 \%$ ). The Cochran's Q test and the $\mathrm{I}^{2}$ statistic by Higgins et al., (2003) show the existence of high heterogeneity in the prevalence of studies included in the metaanalysis: $\mathrm{Q}(8)=110.73 ; p<0.001 ; \mathrm{I}^{2}=92.8 \%$ (Figure 2).

\section{Prevalence of Stress Urinary Incontinence}

The prevalence of studies included in the meta-analysis was $20.7 \% \quad(95 \%$ (CI): $18.5 \%$ $22.9 \%)$. The Cochran's $Q$ test and the $\mathrm{I}^{2}$ statistic by
Higgins et al., (2003) show the existence of high heterogeneity in the prevalence of studies included in the meta-analysis: $\mathrm{Q}(7)=135.67 ; p<$ $0.001 ; I^{2}=94.8 \%$ (91.9\%; 96.7\%) (Figure 3).

\section{Prevalence of Sports}

The prevalence of high-impact sports ranged from 14.3 to $75.6 \%$ (volleyball). The prevalence of studies included in the metaanalysis was $25.6 \%$ (95\% (CI): $23.5 \%-28.1 \%$ ). The Cochran's $Q$ test and the $\mathrm{I}^{2}$ statistic by Higgins et al., (2003) show the existence of high heterogeneity in the prevalence of studies included in the meta-analysis: $\mathrm{Q}(8)=138.00 ; p<$ $0.001 ; \mathrm{I}^{2}=94.2 \%(91.0 \% ; 96.3 \%)$ (Figure 4 ).

\section{Discussion}

The UI is considered the most common PFM dysfunction in female athletes, affecting 15 to $17 \%$ of women every day (Dieter et al., 2015; Teixeira et al., 2018) and SUI is considered the most common type of UI (Dieter et al., 2015; Goldstick and Constantini, 2014; Maia et al., 2015). This systematic review and meta-analysis found that the prevalence of UI among female athletes was $25.9 \%$ and when SUI was analyzed separately, the prevalence was $20.7 \%$. The prevalence in high impact sports was $25.6 \%$, with the highest prevalence observed in volleyball, reaching the value of $75.6 \%$. Several studies also found high prevalence of UI among female athletes (Almousa and Van Loon, 2017; Lourenco et al., 2018; Santos et al., 2018; Teixeira et al., 2018). There is a strong relationship between physical activity and SUI (Goldstick and Constantini, 2014; Hagovska et al., 2017; Teixeira et al., 2018). A possible justification for these higher rates is that intense physical activity promotes an increase in intra-abdominal pressure and the repetitive increases may lead to weakness and stretching of the PFM and, consequently, to UI (Lourenco et al., 2018; Maia et al., 2015; Santos et al., 2018). 
Table 1. Study characteristics

\begin{tabular}{|c|c|c|c|c|c|c|c|}
\hline Study & Sample & Study design & $\begin{array}{l}\text { Age in } \\
\text { years, } \\
\text { mean (SD) }\end{array}$ & Assessment & $\begin{array}{l}\text { Interventio } \\
\mathrm{n}\end{array}$ & Results & $\begin{array}{l}\text { Quality } \\
\text { Score } \\
\text { (Down and } \\
\text { Black) }\end{array}$ \\
\hline $\begin{array}{l}\text { Borin et al., } \\
2013\end{array}$ & $\begin{array}{l}\mathrm{N}=40 \\
\text { Volleyball } \quad(\mathrm{n}=10) \\
\text { Handball } \quad(\mathrm{n}=10) \\
\text { Basketball } \quad(\mathrm{n}=10) \\
\text { Nonathletes }(\mathrm{n}=10)\end{array}$ & $\begin{array}{l}\text { Prospective } \\
\text { Observational }\end{array}$ & $24.0(8.48)$ & Perineometer & $\begin{array}{l}\text { Volleyball } \\
\text { Handball } \\
\text { Basketball }\end{array}$ & $\begin{array}{l}\text { Volleyball } \\
20 \% \\
\text { Handball } \\
20 \% \\
\text { Basketball } \\
10 \% \\
\text { Nonathlete } \\
\text { s } 0 \%\end{array}$ & 7 \\
\hline $\begin{array}{l}\text { Da Roza et al., } \\
\text { 2015a }\end{array}$ & $\begin{array}{l}\mathrm{N}=386 \\
\text { Nulliparous } \\
\text { athletes }\end{array}$ & Cross-sectional & $21.4(2.5)$ & ICIQ-SF & $\begin{array}{l}1^{\text {st },} 2^{\text {nd }} 3^{\text {rd and }} \\
4^{\text {th quartile }} \\
(0-30,31-180,181- \\
420,421-2940 \text { min of } \\
\text { exercise/week })\end{array}$ & $\begin{array}{l}\text { SUI } 49.4 \% \\
\text { UUI } 22.1 \% \\
\text { MUI } 28.6 \%\end{array}$ & 10 \\
\hline $\begin{array}{l}\text { Da Roza et al., } \\
2015 b\end{array}$ & $\begin{array}{l}\mathrm{N}=22 \\
\text { Nulliparous / } \\
\text { trampolinists }\end{array}$ & Cross-sectional & $18.1(3.4)$ & $\begin{array}{l}\text { ICIQ-SF } \\
\text { Questionnaire }\end{array}$ & $\begin{array}{l}1^{\text {st }}, 2^{\text {nd }} \text { and } \\
3^{\text {rd }} \text { tertiles }\end{array}$ & SUI $72.7 \%$ & 11 \\
\hline $\begin{array}{l}\text { Ferreira et al., } \\
2014\end{array}$ & $\begin{array}{l}\mathrm{N}=32 \\
\text { (Nulliparous / } \\
\text { volleyball) } \\
\text { Intervention }(\mathrm{n}=16) \\
\text { Control }(\mathrm{n}=16)\end{array}$ & $\begin{array}{l}\text { Experimental } \\
\text { study }\end{array}$ & $\begin{array}{l}\text { Interventio } \\
\text { n } 19.4(3.24) \\
\text { Control } \\
19.1(2.11)\end{array}$ & $\begin{array}{l}\text { Questionnaire } \\
\text { Pad-test } \\
\text { Frequency of } \\
\text { urine leakage (7- } \\
\text { day diary before } \\
\text { and after PFMRP) }\end{array}$ & $\begin{array}{l}\text { 3-months } \\
\text { PFMRP }\end{array}$ & $\begin{array}{l}\text { Interventio } \\
\text { n } 100 \% \\
\text { Control } \\
100 \%\end{array}$ & 8 \\
\hline $\begin{array}{l}\text { Hagovska et al., } \\
2017\end{array}$ & $\begin{array}{l}\mathrm{N}=503 \\
\text { Nulliparous / } \\
\text { High-impact } \\
\text { exercises }\end{array}$ & Cross-sectional & 21.1 (3.6) & $\begin{array}{l}\text { ICIQ-SF } \\
\text { OAB-q } \\
\text { I-QOL } \\
\text { IPAQ-SF }\end{array}$ & $\begin{array}{l}\text { Low MET } \\
(3.3)<600 \\
\text { Moderate } \\
\text { MET }(4.0) \\
600-1500 \\
\text { High MET } \\
\geq 3000\end{array}$ & $\begin{array}{l}\text { SUI } 13.52 \% \\
\text { UUI } 0.80 \%\end{array}$ & 10 \\
\hline $\begin{array}{l}\text { Jácome et al., } \\
2011\end{array}$ & $\begin{array}{l}\mathrm{N}=106 \\
\text { Athletics } \\
(\text { track and field) } \\
(\mathrm{n}=32) \\
\text { Basketball }(\mathrm{n}=36) \\
\text { Indoor football } \\
(\mathrm{n}=38)\end{array}$ & Cross-sectional & $\begin{array}{l}\text { Athletics } \\
20.0(1.8) \\
\text { Basketball } \\
23.7(4.0) \\
\text { Indoor } \\
\text { football } \\
24.0(4.8)\end{array}$ & Questionnaire & $\begin{array}{l}\text { Track and } \\
\text { field, } \\
\text { basketball } \\
\text { and indoor } \\
\text { football }\end{array}$ & $\begin{array}{l}\text { SUI } 61.4 \% \\
\text { UUI } 20.5 \% \\
\text { MUI } 18.2 \%\end{array}$ & 9 \\
\hline $\begin{array}{l}\text { Leitner et al., } \\
2017\end{array}$ & $\begin{array}{l}\mathrm{N}=50 \text { (running) } \\
\text { Continent }(\mathrm{n}=28) \\
\text { SUI }(\mathrm{n}=22)\end{array}$ & $\begin{array}{l}\text { Cross-sectional } \\
\text { and } \\
\text { exploratory } \\
\text { study }\end{array}$ & $\begin{array}{l}\text { Continent } \\
38.7(10.0) \\
\text { SUI } 45.3 \\
(9.5)\end{array}$ & $\begin{array}{l}\text { Surface } \\
\text { eletromyographic } \\
\text { Tripolar vaginal } \\
\text { probe }\end{array}$ & $\begin{array}{l}\text { Running on } \\
\text { a treadmill }\end{array}$ & $\begin{array}{l}\text { No } \\
\text { differences } \\
\text { between } \\
\text { continen } \\
\text { and } \\
\text { incontinent }\end{array}$ & 10 \\
\hline $\begin{array}{l}\text { Póswiata et al., } \\
2014\end{array}$ & $\begin{array}{l}\mathrm{N}=112 \\
\text { Cross-country } \\
\text { skiers }(\mathrm{n}=57) \\
\text { Runners }(\mathrm{n}=55)\end{array}$ & Cross-sectional & $\begin{array}{l}\text { Cross- } \\
\text { country } \\
\text { skiers } \\
26.61(4.41) \\
\text { Runners } \\
29.49(6.02)\end{array}$ & $\begin{array}{l}\text { Questionnaire } \\
\text { UDI-6 }\end{array}$ & $\begin{array}{l}\text { Cross- } \\
\text { country } \\
\text { skiers and } \\
\text { Running }\end{array}$ & SUI $45.54 \%$ & 8 \\
\hline $\begin{array}{l}\text { Rivalta et al., } \\
2010\end{array}$ & $\begin{array}{l}\mathrm{N}=3 \\
\text { Nulliparous / } \\
\text { volleyball }\end{array}$ & NRCT & 30.6 & $\begin{array}{l}\text { Vaginal probe } \\
\text { Urogynecologic } \\
\text { evaluation } \\
\text { Puborectalis test }\end{array}$ & $\begin{array}{l}\text { Volleyball } \\
\text { PFMRP }\end{array}$ & SUI 0\% & 8 \\
\hline
\end{tabular}

Note. ICIQ-SF International Consultation on Incontinence Questionnaire-Short Form, IPAQ-SF International Physical Activity Questionnaire-Short Form, I-QOL Urinary Incontinence Quality of Life Scale, MET Metabolic Equivalent, MUI Mixed Urinary Incontinence, OAB-q Overactive Bladder Questionnaire, PFMRP Pelvic floor muscle rehabilitation program, SUI Stress Uriary Incontinence, UDI-6 Urogenital Distress Inventory, UUI Urgency Urinary Incontinence. 
Table 2 Assessment of the quality of the studies

\begin{tabular}{llllll}
\hline Reference & Reporting & External validity & Bias & $\begin{array}{l}\text { Selection variable } \\
\text { (Confounding and Power) }\end{array}$ & Final score \\
Borin et al., 2013 & 5 & 0 & 2 & 0 & $\mathbf{7}$ \\
Da Roza et al., 2015a & 6 & 0 & 3 & 1 & $\mathbf{1 0}$ \\
Da Roza et al., 2015b & 6 & 0 & 3 & 2 & $\mathbf{1 1}$ \\
Ferreira et al., 2014 & 5 & 0 & 2 & 1 & $\mathbf{8}$ \\
Hagovska et al., & 5 & 0 & 2 & 1 & $\mathbf{8}$ \\
2017 & & & 3 & 0 & $\mathbf{8}$ \\
Jácome et al., 2011 & 5 & 0 & 3 & 2 & $\mathbf{1 0}$ \\
Leitner et al., 2017 & 5 & 0 & 2 & 1 & $\mathbf{8}$ \\
Póswiata et al., 2014 & 5 & 0 & 1 & 2 & $\mathbf{8}$ \\
Rivalta et al., 2010 & 5 & 0 & & & \\
\hline
\end{tabular}

Note. The values refer to the score of the studies on certain domains (sub-scales) of the adapted Downs and Black Scale
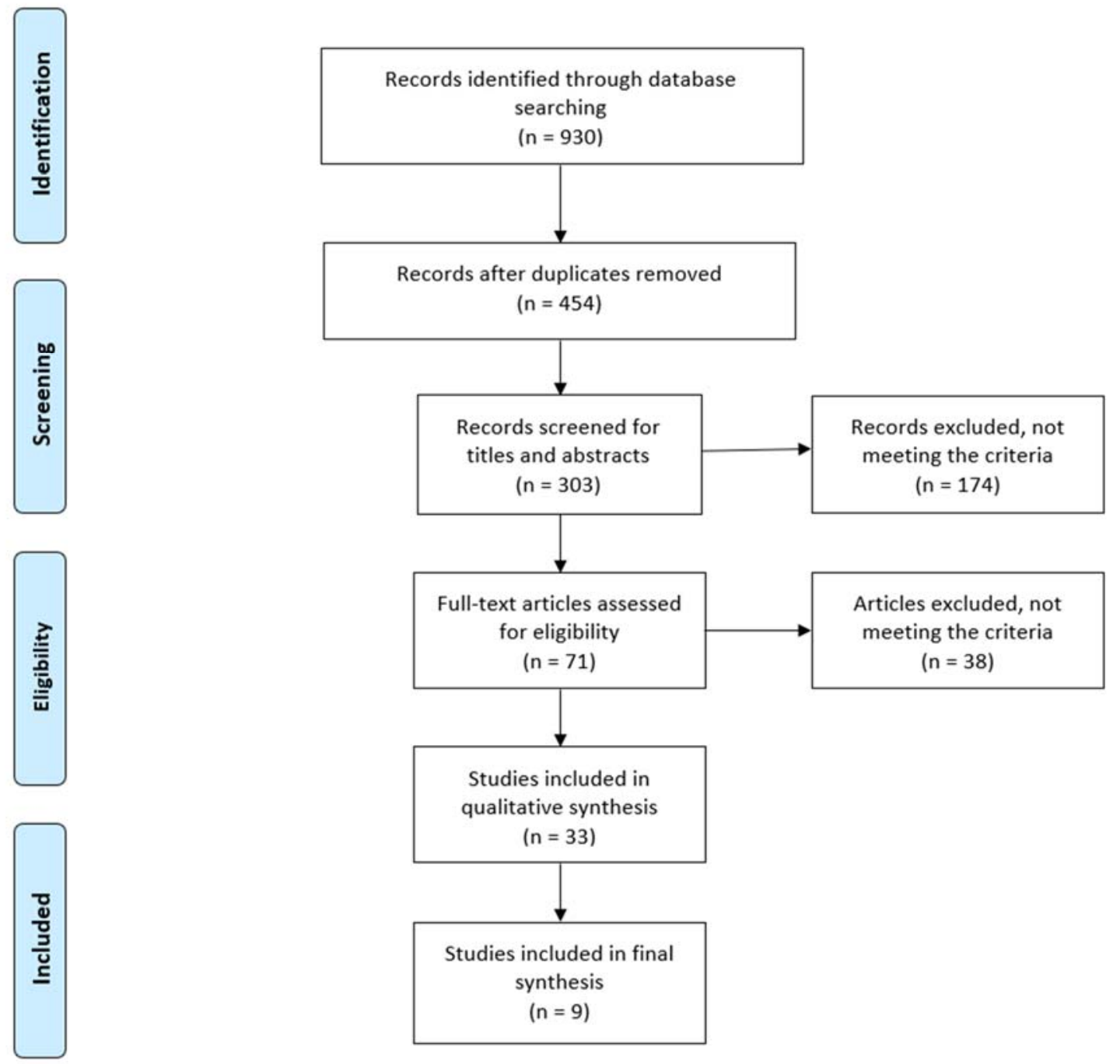

Figure 1. Flow diagram for study selection. 


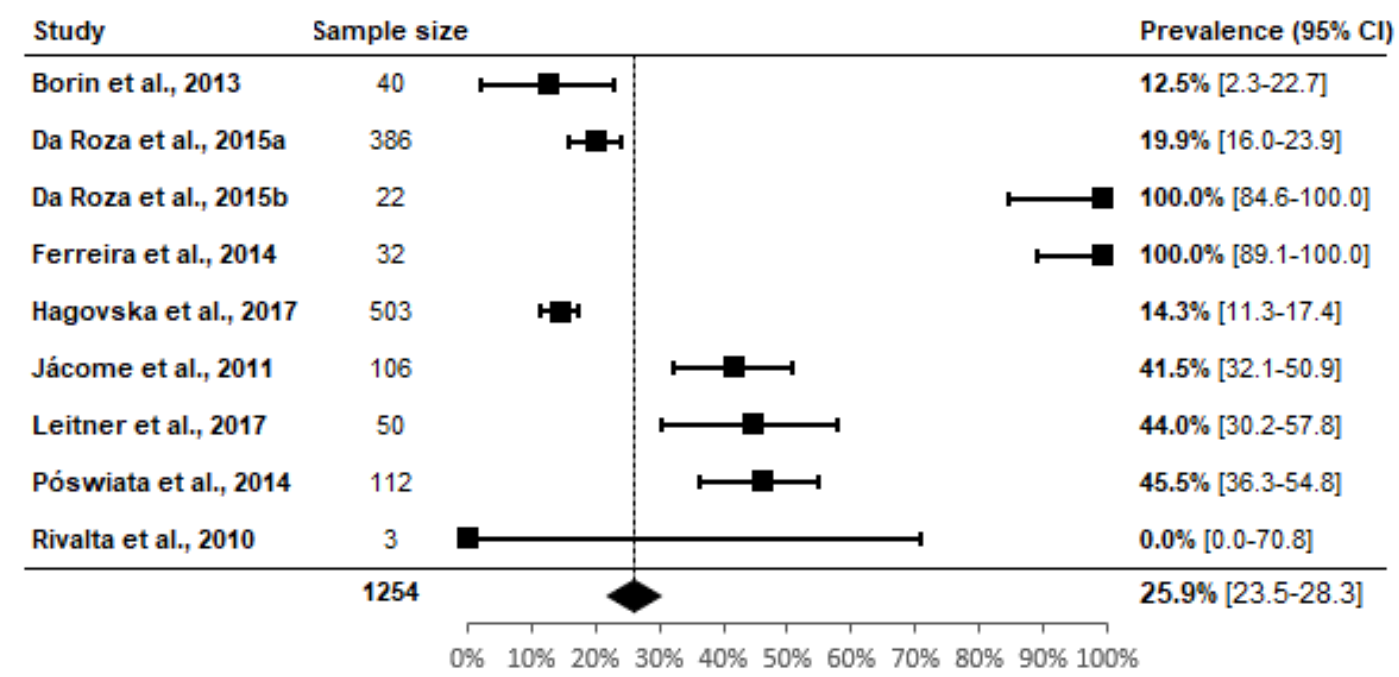

Figure 2. Prevalence of urinary incontinence in female athletes (Test of heterogeneity: $Q(8)=110.73 ; p<0.001 ; I^{2}=92.8 \%[88.5 \% ; 95.5 \%]$ )

\begin{tabular}{|c|c|c|c|}
\hline Study & Sample size & & Prevalence $(95 \% \mathrm{Cl})$ \\
\hline Borin et al., 2013 & $40 \quad \longmapsto$ & & $12.5 \%[2.3-22.7]$ \\
\hline Da Roza et al., 2015a & Her & & $9.8 \%[6.9-12.8]$ \\
\hline Da Roza et al., 2015b & 22 & $\longrightarrow$ & $72.7 \%[54.1-91.3]$ \\
\hline Ferreira et al., 2014 & 32 & $\longmapsto$ & $100.0 \%[89.1-100.0]$ \\
\hline Hagovska et al., 2017 & Hit & & $13.5 \%[10.5-16.5]$ \\
\hline Jácome et al., 2011 & 44 & & $61.4 \%[47.0-75.8]$ \\
\hline Leitner et al., 2017 & 50 & $\longrightarrow$ & 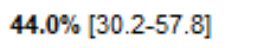 \\
\hline Póswiata et al., 2014 & 112 & $\longmapsto$ & $45.5 \%[36.3-54.8]$ \\
\hline & 1189 & & $20.7 \%[18.5-22.9]$ \\
\hline
\end{tabular}

Figure 3. Prevalence of stress urinary incontinence in female athletes (Test of heterogeneity: $Q(7)=166.787 ; p<0.001 ; I^{2}=95.8 \%[93.6 \% ; 97.3 \%]$ ) 


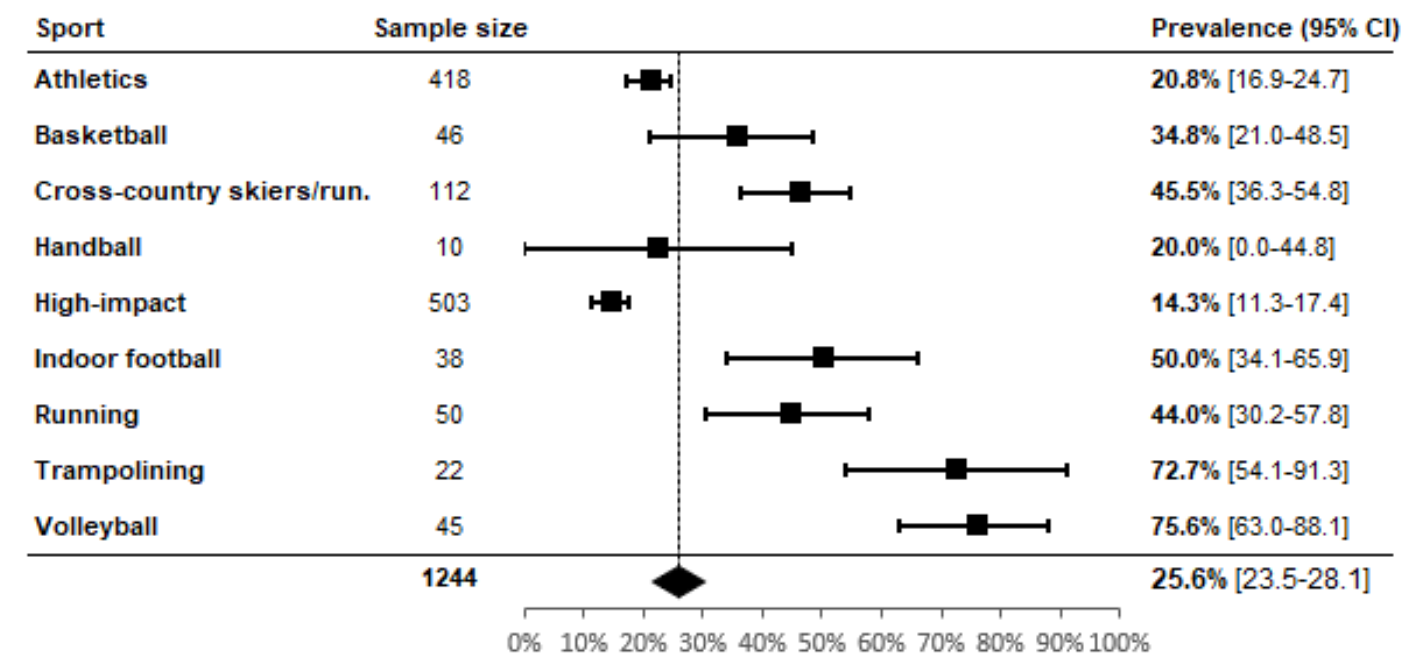

Figure 4. Prevalence of urinary incontinence in high-impact sports

(Test of heterogeneity: $Q(8)=138.00 ; p<0.001 ; I^{2}=94.2 \%[91.0 \% ; 96.3 \%]$ )

This increase in abdominal pressure results in morphologic and functional modifications, such as deformation of ligaments and connective tissue (Da Roza et al., 2015b; Fozzatti et al., 2012; Kruger et al., 2007; Lourenco et al., 2018). This is believed to be the cause of urinary dysfunctions in young and nulliparous women who have no other risk factor when they reach the pressure threshold on the PFM (Lourenco et al., 2018; Nygaard et al., 2012).

However, several studies also showed that intense physical activity could strengthen the PFM through the co-contraction between them and the abdominal muscles (Bø, 2004; Santos et al., 2018). Some studies used tests involving high impact exercise (running and jumping) before and after treatment, and showed that it is possible to cure or reduce UI during physical activity $(\mathrm{B} \varnothing$, 2004; Junginger et al., 2014; Mørkved et al., 2002; Santos et al., 2018) and to delay or avoid surgery (Bø and Hilde, 2013).

Female athletes report high prevalence of
UI in high-impact sports (Almousa and Van Loon, 2017; Bø and Borgen, 2001; Eliasson et al., 2002; Santos et al., 2018). High impact activities were defined as those involving the performance of several jumps and actions related to maximum abdominal contractions. These increase intraabdominal pressure and exert an impact force directly on the PFM (Bø, 2004; Casey and Temme, 2017; Reis et al., 2011; Santos et al., 2018; Teixeira et al., 2018). Thus, we classified all sports that involved jumping and running as high impact (Carvalhais et al., 2018; Mitchell et al., 2005). For high impact exercises, this review presents a new record in the prevalence of UI, showing prevalence in volleyball of $75.6 \%$. The other sports showed the following prevalence: $72.7 \%$ for trampolining, 50\% for indoor soccer, $45.5 \%$ for cross-country skiers and runners, $44 \%$ for running, 34.8\% for basketball, $20.8 \%$ for athletics and $20 \%$ for handball. Until now, several studies have pointed to jumping and trampolining as having the highest prevalence of UI in high 
impact sports. Some authors corroborate that the prevalence of UI ranges from 28 to $80 \%$, with the highest prevalence in high impact female athletes, such as trampolinists, gymnasts, hockey players and ballet dancers (Carls, 2007; Goldstick and Constantini, 2014; Simeone et al., 2010). Jumping is the activity that is most likely to provoke UI. Corroborating this review, Reis et al. (2011) found $50 \%$ prevalence of SUI in basketball players and $30 \%$ in volleyball players, classifying these sports as being at a high risk for UI. Other authors report more athletes experience leakage during training rather than competition (95.2 vs. $51.2 \%$ ), possibly because of higher catecholamine levels during competition that act on the urethral $\alpha$-receptors to maintain its closure (Goldstick and Constantini, 2014; Thyssen et al., 2002). Forty percent prevalence was found among all high impact sports, which included team sports, track and field, and aerobics; Eliasson et al. (2002) found $80 \%$ prevalence of UI among trampoline athletes and Almeida and Machado (2017) found that $37.5 \%$ of women who practiced jumps (an aerobic activity with repeated jumping) reported they had experienced UI.

This systematic review and meta-analysis demonstrate that the prevalence of UI could be high in female athletes and that high impact sports can increase the risk for UI. SUI may be a barrier to women's participation in sport and fitness activities and, consequently, decrease the quality of life of athletes. This systematic review also confirmed that volleyball (a high impact sport) was the sport with the highest prevalence of SUI. Understanding the effect of the risk factor mechanisms on the PFM will enable us to implement preventive strategies and advise appropriately on the prevention of UI. It is very important to sensitize all the professionals (physiotherapists, coaches, fitness instructors and sports doctors) involved to timely detect or prevent SUI.

The limitation of the study is in fact the variability of outcome measures and the heterogeneity of the study designs. Some studies used one single measure as the main outcome, while other studies combined several measures. In some studies, only the questionnaire was used to assess the prevalence of SUI symptoms. It correlates very well with urodynamic tests or other urogenital diagnostic (e.g. pad test, voiding diaries). Further clinical studies should be performed to analyze the prevalence of UI, including more reliable diagnostics.

\section{Acknowledgments}

This work is supported by National Funds by FCT - Portuguese Foundation for Science and Technology, under the projects UIDB/04033/2020 and UID04045/2020

\section{References}

Abrams P, Andersson K, Birder L, Brubaker L, Cardozo L, Chapple C, Cottenden A, Davila W, De Ridder D, Dmochowski R. Fourth International Consultation on Incontinence Recommendations of the International Scientific Committee: evaluation and treatment of urinary incontinence, pelvic organ prolapse, and fecal incontinence. Neurourol Urodyn, 2010; 29: 213-240

Almeida PP, Machado LRG. The prevalence of urinary incontinence in women practicing of jump. Fisioter Mov, 2017; 25: 55-65

Almousa S, Van Loon AB. The prevalence of urinary incontinence in nulliparous adolescent and middleaged women and the associated risk factors: a systematic review. Maturitas, 2017; 107: 78-83

Bø K. Urinary incontinence, pelvic floor dysfunction, exercise and sport. Sports Med, 2004; 34: 451-464

Bo K, Berghmans B, Morkved S, Van Kampen M. Evidence-based physical therapy for the pelvic floor: bridging science and clinical practice, Elsevier Health Sciences; 2007

Bø K, Borgen JS. Prevalence of stress and urge urinary incontinence in elite athletes and controls. Med Sci Sports Exerc, 2001; 33: 1797-1802

Bø K, Hilde G. Does it work in the long term?-A systematic review on pelvic floor muscle training for female stress urinary incontinence. Neurourol Urodyn, 2013; 32: 215-223 
Borin Da Silva LCM, Nunes FR, De Oliveira Guirro EC. Assessment of pelvic floor muscle pressure in female athletes. PMR, 2013; 5: 189-193

Carls C. The prevalence of stress urinary incontinence in high school and college-age female athletes in the midwest: implications for education and prevention. Urol Nurs, 2007; 27: 21-24, 39

Carvalhais A, Jorge RN, Bø K. Performing high-level sport is strongly associated with urinary incontinence in elite athletes: a comparative study of 372 elite female athletes and 372 controls. Br J Sports Med, 2018; 52: $1586-1590$

Casey EK, Temme K. Pelvic floor muscle function and urinary incontinence in the female athlete. Physician Sports Med, 2017; 45: 399-407

Caylet N, Fabbro-Peray P, Marès P, Dauzat M, Prat-Pradal D, Corcos J. Prevalence and occurrence of stress urinary incontinence in elite women athletes. Canadian J Urology, 2006; 13: 3174-3179

Collaboration TC. Cochrane Library. Recent Findings, 2019. Available at: http://www.thecochranelibrary.com/view/0/index-html; accessed on 31.01.2019

Da Roza T, Brandão S, Mascarenhas T, Jorge RN, Duarte JA. Urinary incontinence and levels of regular physical exercise in young women. Int J Sports Med, 2015a; 36: 776-780

Da Roza T, Brandão S, Mascarenhas T, Jorge RN, Duarte JA. Volume of training and the ranking level are associated with the leakage of urine in young female trampolinists. Clin J Sport Med, 2015b; 25: 270-275

Da Roza T, De Araujo MP, Viana R, Viana S, Jorge RN, Bø K, Mascarenhas T. Pelvic floor muscle training to improve urinary incontinence in young, nulliparous sport students: a pilot study. Int Urogynecol J, 2012; 23: 1069-1073

Dieter AA, Wilkins MF, Wu JM. Epidemiological trends and future care needs for pelvic floor disorders. Curr Opin Obstet Gynecol, 2015; 27: 380-384

Downs SH, Black N. The feasibility of creating a checklist for the assessment of the methodological quality both of randomised and non-randomised studies of health care interventions. J Epidemiol Community Health, 1998; 52: 377-384

Eliasson K, Edner A, Mattsson E. Urinary incontinence in very young and mostly nulliparous women with a history of regular organised high-impact trampoline training: occurrence and risk factors. Int Urogynecol J, 2008; 19: 687-696

Eliasson K, Larsson T, Mattsson E. Prevalence of stress incontinence in nulliparous elite trampolinists. Scandinavian J Med Sci Sports, 2002; 12: 106-110

Ferreira S, Ferreira M, Carvalhais A, Santos PC, Rocha P, Brochado G. Reeducation of pelvic floor muscles in volleyball athletes. Rev Assoc Med Bras, 2014; 60: 428-433

Fozzatti C, Riccetto C, Herrmann V, Brancalion MF, Raimondi M, Nascif CH, Marques LR, Palma PP. Prevalence study of stress urinary incontinence in women who perform high-impact exercises. Int Urogynecol J, 2012; 23: 1687-1691

Goldstick O, Constantini N. Urinary incontinence in physically active women and female athletes. Br J Sports Med, 2014; 48:296-8

Hagovska, M, Švihra J, Buková A, Hrobacz A, Dračková D, Švihrová V, Kraus L. Prevalence of urinary incontinence in females performing high-impact exercises. Int J Sports Med, 2017; 38: 210-6

Haylen, BT, De Ridder D, Freeman RM, Swift SE, Berghmans B, Lee J, Minga A, Petri E, Rizk DE, Sand PK, Schaer GN. An International Urogynecological Association (IUGA)/International Continence Society (ICS) joint report on the terminology for female pelvic floor dysfunction. Neurourol Urodyn, 2010; 29: 420

Higgins JP, Thompson SG, Deeks JJ, Altman DG. Measuring inconsistency in meta-analyses. BMJ, 2003; 327: $557-60$

Jácome C, Oliveira D, Marques A, Sá-Couto P. Prevalence and impact of urinary incontinence among female athletes. Int J Gynaecol Obstet, 2011; 114: 60-3

Jeyaseelan SM, Roe BH, Oldham JA. The use of frequency/volume charts to assess urinary incontinence. Phys Ther Rev, 2000; 5: 141-6

Junginger, B, Seibt E, Baessler K. Bladder-neck effective, integrative pelvic floor rehabilitation program: follow-up investigation. Eur J Obstet Gynecol Reprod Biol, 2014; 174: 150-3

Kruger J, Dietz H, Murphy B. Pelvic floor function in elite nulliparous athletes. Ultrasound in Obstet Gynecol, 2007; 30: 81-5 
Leitner M, Moser H, Eichelberger P, Kuhn A, Radlinger L. Evaluation of pelvic floor muscle activity during running in continent and incontinent women: an exploratory study. Neurourol Urodyn, 2017; 36: 1570-6

Leitner M, Moser H, Eichelberger P, Kuhn A, Radlinger L. Pelvic floor muscle activity during fast voluntary contractions in continent and incontinent women. Neurourol Urodyn, 2019; 38(2): 625-631

Lourenco TRM, Matsuoka PK, Baracat EC, Haddad JM. Urinary incontinence in female athletes: a systematic review. Int Urogynecol J, 2018; 29: 1757-63

Maia M, Da Roza T, Mascarenhas T. Female athlete pelvic floor-urogynecological overview O pavimento pélvico da mulher atleta-perspectiva uroginecológica. Acta Obstet Ginecol Port, 2015; 9: 56-64

Mitchell JH, Haskell W, Snell P, Van Camp SP. Task Force 8: classification of sports. J American College of Cardiology, 2005; 45: 1364-7

Moher D, Shamseer L, Clarke M, Ghersi D, Liberati A, Petticrew M, Shekelle P, Stewart LA. Preferred reporting items for systematic review and meta-analysis protocols (PRISMA-P) 2015 statement. Syst Rev, 2015; 4: 1-9

Mørkved S, Bø K, Fjørtoft T. Is there any additional effect off adding biofeedback to pelvic floor muscle training? A single-blind randomized controlled trial. Obstet Gynecol, 2002; 100: 730-9

Nygaard I, Shaw J, Egger MJ. Exploring the association between lifetime physical activity and pelvic floor disorders: study and design challenges. Contemp Clin Trials, 2012; 33: 819-27

Oliveira M, Ferreira M, Azevedo MJ, Firmino-Machado J, Santos PC. Pelvic floor muscle training protocol for stress urinary incontinence in women: a systematic review. Rev Assoc Med Bras, 2017; 63: 642-50

Poświata A, Socha T, Opara J. Prevalence of stress urinary incontinence in elite female endurance athletes. J Hum Kinet, 2014; 44: 91-6

Reis AO, Câmara CNS, Santos SG, Dias TS. Comparative study of pelvic floor contraction capacity in volleyball and basketball athletes. Rev Bras Med Sports, 2011; 17: 97-101

Rivalta M, Sighinolfi MC, Micali S, De Stefani S, Torcasio F, Bianchi G. Urinary incontinence and sport: first and preliminary experience with a combined pelvic floor rehabilitation program in three female athletes. Health care Women Int, 2010; 31: 435-43

Santos KM, Da Roza T, Mochizuki L, Arbieto ERM, Da Luz SCT. Assessment of abdominal and pelvic floor muscle function among continent and incontinent athletes. Int Urogynecol J, 2019; 30: 693-99

Schwarzer G. meta: An R package for meta-analysis. R News, 2007; 7: 40-5

Simeone C, Moroni A, Pettenò A, Antonelli A, Zani D, Orizio C, Cunico SC. Occurrence rates and predictors of lower urinary tract symptoms and incontinence in female athletes. Urology J, 2010; 77: 139-46

Sousa M, Viana R, Viana S, Da Roza T, Azevedo R, Araújo M, Festas C, Mascarenhas T, Jorge RN. Effects of a pelvic floor muscle training in nulliparous athletes with urinary incontinence: biomechanical models protocol. Computational and Experimental Biomedical Sciences: Methods and Applications: Springer, Cham, 83-90; 2015

Team RC. R: A language and environment for statistical computing. R Foundation for Statistical Computing 2015, Vienna, Austria. ISBN 3-900051-07-0. Available: http://www. R-project. org/(1.12. 2015); 2016

Teixeira RV, Colla C, Sbruzzi G, Mallmann A, Paiva LL. Prevalence of urinary incontinence in female athletes: a systematic review with meta-analysis. Int Urogynecol J, 2018; 29: 1717-25

Thomaz RP, Colla C, Darski C, Paiva LL. Influence of pelvic floor muscle fatigue on stress urinary incontinence: a systematic review. Int Urogynecol J, 2018; 29: 197-204

Thyssen H, Clevin L, Olesen S, Lose G. Urinary incontinence in elite female athletes and dancers. Int Urogynecol J, 2002; 13: 15-7

Viana R, Viana S, Neto F, Mascarenhas T. Adaptation and validation of the King's Health Questionnaire in Portuguese women with urinary incontinence. Int Urogynecol J, 2015; 26: 1027-33

\section{Corresponding author:}

\section{Telma Pires, PhD}

University of Trás-os-Montes and Alto Douro; Quinta de Prados, 5000-801 Vila Real;

Phone: +351 259350 000, Fax: +351 259325058

Email adress: telmafilipapires@gmail.com 